\title{
Congenital para-oesophageal hernia in a young infant presenting with pneumonia
}

\author{
Pierre Goussard (1) , ${ }^{1}$ Savvas Andronikou, ${ }^{2}$ Lunga Mfingwana, ${ }^{1}$ Jacques Janson ${ }^{3}$
}

${ }^{1}$ Department of Paediatrics and Child Health, Faculty of Medicine and Health Sciences, Stellenbosch University, Cape Town, South Africa ${ }^{2}$ Department of Pediatric Radiology, University of Pennsylvania, Philadelphia, Pennsylvania, USA

${ }^{3}$ Department of Cardiothoracic Surgery, Faculty of Medicine and Health Sciences, Stellenbosch University, Cape Town, South Africa

\section{Correspondence to} Professor Pierre Goussard; pgouss@sun.ac.za

Accepted 4 March 2021

\section{DESCRIPTION}

A 13-week-old female infant presented to a tertiary hospital with a 5-day history of coughing, feeding difficulty, vomiting and tachypnoea. She was previousy well, her weight plots followed the median weight-for-age $\mathrm{Z}$ score and her immunisation record was up to date. No antenatal ultrasound was performed during the pregnancy. The infant had no history of exposure to either Mycobacterium tuberculosis or SARS-CoV-2.

The infant was admitted for further investigations of a provisional diagnosis of community-acquired pneumonia. Her oxygen saturation was $98 \%$ on room air, with a respiratory rate of 38 breaths/min and no signs of respiratory distress. On examination, no obvious dysmorphic features were noted, and the patient appeared well nourished.

On chest auscultation, decreased right-sided ventilation was detected, with no crepitations nor wheezing. The PCR test for HIV was negative; the full blood count revelaed a normal leucocyte count and the $\mathrm{C}$ reactive protein was $<1 \mathrm{mg} / \mathrm{L}$. The blood culture was negative after 5 days and no viruses were isolated from a nasopharyngeal aspirate. Amoxicillin/clavulanic acid treatment was stopped after 72 hours.

Plain chest radiographs (figure 1A,B) demonstrated a soft tissue mass in the right lower thorax, with central lucency, with expansion of the right middle and upper lobes across the midline and consequent associated cardiac displacement to the left. The stomach bubble was visible in the left hypochondrium. This prompted a CT scan for evaluation of the chest mass (figure 2A,B), which confirmed the findings made on the initial chest

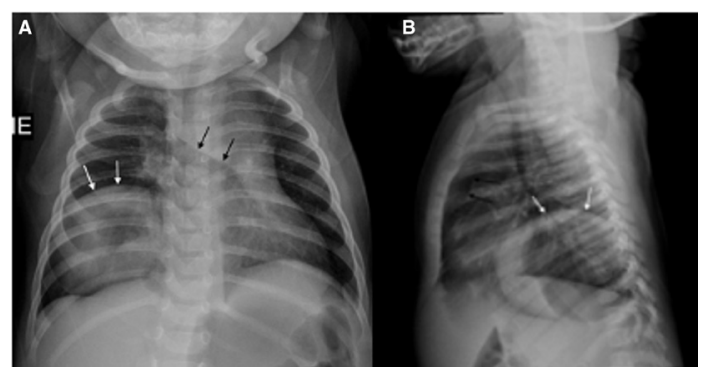

(c) BMJ Publishing Group Limited 2021. No commercial re-use. See rights and permissions. Published by BMJ.

To cite: Goussard P,
Andronikou S, Mfingwana L,
et al. BMJ Case Rep
2021;14:e242037.
doi:10.1136/bcr-2021-
242037

Figure 1 Plain radiographs: frontal (A) and lateral chest radiographs $(B)$ in a 13-week-old girl demonstrate a soft tissue mass in the lower right hemithorax with a sharply marginated convex superior margin (white arrows) and central gas lucency. There is a visible 'stomach bubble' in the left hypochondrium. The heart is displaced to the left and there is substernal herniation of the right lung herniation across the midline (black arrows).

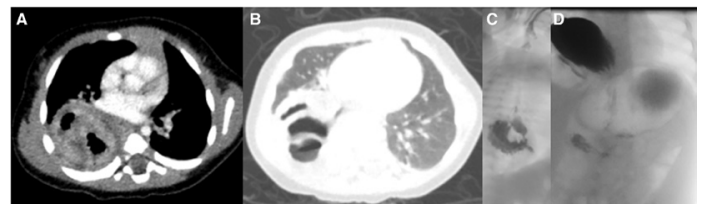

Figure 2 CT scan of the chest. Axial CT images with soft tissue (A) and lung windows (B) confirm the soft tissue mass posteriorly in the left hemithorax with central air pockets, causing atelectasis of portions of the left lower lobe and hyperexpansion of the right middle lobe across the midline at the substernal level. The lung window is suggestive of the mass being comprised of bowel wall and lumen. The heart is displaced to the left upper gastrointestinal tract series: early swallowing phase (C) and later gastric filling phase (D) of an upper gastrointestinal study demonstrate the gastro-oesophageal junction in the thorax and filling of the gastric fundus within the right thorax alongside the oesophagus, in keeping with a mixed-type paraoesophageal 'rolling' and sliding-type hernia. Subphrenic contrast is observed in the body of the stomach and small bowel.

radiographs, with the exception of an impression of bowel wall and lumen within the chest cavity. This, in turn, prompted an upper gastrointestinal tract study (figure 2C,D), which demonstrated passage of contrast through an intra-thoracic located gastrooesophageal junction, as well as herniation of the gastric fundus alongside the oesophagus into the right hemithorax, in keeping with a diagnosis of a mixed-type para-oesophageal sliding-type hernia. The body of the stomach remained in the left hypochondrium, accounting for the observation of a stomach bubble in the normal anatomical location on plain radiographs.

A right-sided thoracotomy was performed through the sixth intercoastal space. The oesophagus and large hernia sac was identified and carefully mobilised up to the level of the diaphragm. A Belsey-type repair of the hiatus hernia was performed; hiatus sutures were placed posteriorly and the stomach reduced by placing sutures from the oesophagus to the gastric fundus wall through the diaphragm at the level of the hiatus. The posterior sutures to the hiatus was subsequently tied and the distal oesophagus mobilised in order to gain sufficient length so that the entire stomach could be reduced below the diaphragm. The baby had an uncomplicated postsurgical course and follow-up contrast study demonstrated that the stomach was normally positioned below the diaphragm. 
Hiatus hernia is an uncommon finding in young infants. ${ }^{1}$ Most of these defects in the paediatric age group are acquired, with congenital hiatus hernia rarely encountered. Hiatus hernia consists of either the sliding type (95\%) or para-oesophageal type $(5 \%) .{ }^{2}$ In the case of a sliding-type hernia, the gastro-oesophageal junction moves upwards to an intrathoracic position. In the case of a para-oesophageal hernia, a portion of the stomach migrates into the thorax alongside the gastro-oesophageal junction, while the position of the gastro-oesophageal junction remains fixed

\section{Learning points}

- Congenital para-oesophageal hernia in a young infant can present with pneumonia.

- Hiatus hernia is an uncommon finding in young infants, with congenital hiatus hernia being rare.

- Hiatus hernia in a young infant must be differentiated from other congenital cystic lung lesions. just below the level of the diaphragm. In the latter scenario, the herniated stomach sac is contained in the posterior mediastinum. ${ }^{3}$

Contributors LM and PG was responsible for the medical management. JJ was the surgeon involved. SA was responsible for the radiology. All authors were involved in writing the manuscript.

Funding The authors have not declared a specific grant for this research from any funding agency in the public, commercial or not-for-profit sectors.

Competing interests None declared.

Patient consent for publication Obtained.

Provenance and peer review Not commissioned; externally peer reviewed.

\section{ORCID iD}

Pierre Goussard http://orcid.org/0000-0003-1146-1307

\section{REFERENCES}

1 Karpelowsky JS, Wieselthaler N, Rode H. Primary paraesophageal hernia in children. $J$ Pediatr Surg 2006;41:1588-93.

2 Baglaj SM, Noblett HR. Paraoesophageal hernia in children: familial occurrence and review of the literature. Pediatr Surg Int 1999;15:85-7.

3 Weston AP. Hiatal hernia with cameron ulcers and erosions. Gastrointest Endosc Clin N Am 1996;6:671-9.

Copyright 2021 BMJ Publishing Group. All rights reserved. For permission to reuse any of this content visit

https://www.bmj.com/company/products-services/rights-and-licensing/permissions/

BMJ Case Report Fellows may re-use this article for personal use and teaching without any further permission.

Become a Fellow of BMJ Case Reports today and you can:

- Submit as many cases as you like

- Enjoy fast sympathetic peer review and rapid publication of accepted articles

- Access all the published articles

Re-use any of the published material for personal use and teaching without further permission

Customer Service

If you have any further queries about your subscription, please contact our customer services team on +44 (0) 2071111105 or via email at support@bmj.com.

Visit casereports.bmj.com for more articles like this and to become a Fellow 